\title{
To study the relation of anthropometric factors with total and differential leucocyte count in healthy newborns
}

\author{
$\operatorname{Kumar} \mathbf{A}^{1}, \operatorname{Singh} \mathbf{J}^{2}, \operatorname{kumar} \mathbf{I}^{3}$ \\ ${ }^{1}$ Dr Ashwani Kumar, Senior Resident, Department Of Paediatrics, SGRDIMSAR, Amritsar, ${ }^{2}$ Dr Jaswir Singh Professor \\ \& Head, Department of Paediatrics, Govt. Medical College \& Hospital, Patiala, ${ }^{3}$ Dr Ish Kumar, Professor \& Head, \\ Department of Pathology, Govt. Medical College \& Hospital, Patiala.
}

Address for correspondence: Dr Ashwani Kumar, Email- kumarashwani91@yahoo.com

\begin{abstract}
Introduction: The normal blood picture in newborn infant has been the subject of several studies since the beginning of this century. Several studies were conducted to evaluate relation of hematological parameters of neonate with a perinatal events, maternal and neonatal factors. But only few studies were conducted to compare hematological values of neonate with anthropometric parameters. Objective of this study is to evaluate the effect of neonatal anthropometric factors i.e. weight, including head circumference and length on total and differential leucocyte count in cord blood of healthy newborns. Material \& Methods: The study was conducted on 200 healthy newborns admitted in neonatology section of Department of Paediatrics, Govt. Medical College/ Rajindra Hospital, Patiala. Cord blood sample (2ml) was taken at birth by milking the cord into an EDTA containing vial then used for calculating total leucocyte count and differential leucocyte count. TLC was done by manual method (haemocytometer method) using improved Neubauer Chamber. Results \& conclusion: it can be inferred that Total leucocyte count increases with increasing weight and length of the newborn. Similarly, neutrophils and lymphocytes increases with increasing weight whereas only lymphocytes increases with increasing length of the newborn. However, head circumference has no effect on Total and differential leucocyte count in healthy newborns.
\end{abstract}

Keywords: TLC- Total leucocyte count, DLC- Differential leucocyte count, EDTA- Ethylenediaminetetraacetic acid.

\section{Introduction}

The normal blood picture in newborn infant has been the subject of several studies since the beginning of this century. One of the earliest studies reported that there was leucocytosis as well as presence of erythroid precursors in the infant's blood at birth and leucocytosis with predominant cell being lymphocyte which increased greatly after meals $[1,2]$. However, the first systematic study in this direction found that leucocyte count reached to a maximum value in first $12 \mathrm{hrs}$, by studying infants serially every $6 \mathrm{hrs}$ for first $48 \mathrm{hrs}$ [3]. Furthermore, the variations of blood counts in preterms with different sampling sites [4] and difference in hematological parameters in the newborns from infants and adults were studied [5, 6, 7]. Additionaly, several studies were conducted to evaluate relation of hematological parameters of neonate with a perinatal

Manuscript received: $27^{\text {th }}$ June 2016

Reviewed: $10^{\text {th }}$ July 2016

Author Corrected; $18^{\text {th }}$ July 2016

Accepted for Publication: $30^{\text {th }}$ July 2016 events, maternal and neonatal factors $[8,9,10]$. But only few studies were conducted to compare hematological values of neonate with anthropometric parameters [11, 12]. One such study was done to compare the haematological value (reference range) among Small for gestational age-low birth weight (SGA-LBW), appropriate for gestational age-low birth weight (AGA-LBW) and normal birth weight (NBW) babies. Total 90 (ninety) newborn babies were enrolled in this study. They were ultimately divided into three groups as Group I (SGA-LBW), Group II (AGALBW), Group III (NBW). In group I, 19 (63.3\%) were preterm and $11(36.7 \%)$ were term. In group II, $30(100 \%)$ were preterm and in group III, $30(100 \%)$ were term No significant differences of total count of WBC and platelet counts were not found among different groups [12]. Thus although studies were done to find relation between neonatal weight with TLC and DLC, but none was done with relation to other 
anthropometric measures such as length and head circumference of the neonate. Therefore, objective of this study is to evaluate the effect of neonatal anthropometric factors i.e. weight, including head circumference and length on total and differential leucocyte count in cord blood of healthy newborns.

\section{Material and Methods}

The study was conducted on 200 healthy newborns admitted in neonatology section of Department of Paediatrics, Govt. Medical College/ Rajindra Hospital, Patiala. Babies born to mother with following conditions were excluded from the study:-Pregnancy induced hypertension (PIH), Gestational diabetes, Fever, Prolonged labour , Premature rupture of membranes, Foul smelling liquor, Dai handling, Multiple vaginal examinations, Instrumentation during delivery. Similarly, the babies with following conditions at birth or after 24 hours of life were excluded from the study:Septicemia, Birth asphyxia, Respiratory distress syndrome, Blood group incomptiability, Intraventricular hemorrhage, Congenitaly malformed babies, Small for gestational age and Large for gestational age.The babies were classified as appropriate for gestational age (AGA), small for gestational age (SGA) and large for gestational age (LGA) [13]. AGA are babies whose birth weight is between $10^{\text {th }}$ and $90^{\text {th }}$ percentile of the weight for that gestational age, SGA are the babies whose birth weight is $<10^{\text {th }}$ percentile of the weight for that gestational age and LGA are the babies whose birth weight is $>90^{\text {th }}$ percentile of the weight for that gestational age.Cord blood sample $(2 \mathrm{ml})$ was taken at birth by milking the cord into an EDTA containing vial. EDTA blood was then used for calculating total leucocyte count and differential leucocyte count. TLC was done by manual method (haemocytometer method) using improved Neubauer Chamber. Next, using a WBC pipette, blood was filled upto 0.5mark and the WBC diluting fluid (Turk's fluid) was drawn till the 11 mark.

TURK's Fluid: Composition of fluid is Glecial Acetic Acid - 1.5ml (it hemolyses red cells), Gentian Violet (1\% solution) $-1.5 \mathrm{ml}$ (it stains the nuclei of leucocytes). Distilled water to ...100ml. Fluid and blood was mixed gently. Then Neubauer's chamber was charged with WBC pipette. Using low power objective (20x), WBCs were counted in the four larger corner squares. The number of WBC's per cumm were calculated as follow:

$$
\mathrm{WBC} / \mathrm{Cmm}=\frac{\text { Cellscounted } \mathrm{x} \text { dilutionfactor } \mathrm{x} \text { depthfactor }}{\text { Area of chamberscounted }}
$$

where, dilution in factor $=20$, depth factor $=10$, area of chambers $=4$

DLC was done in smear made from the EDTA blood stained by Leishman stain (Romanowsky group) in body and tail part following Z pattern. ${ }^{[14]}$ Statistical Methods:- Descriptive statistical analysis was carried out in the present study. Mean, standard deviation (SD), t-test, and analysis of variance tests were used to test the significance of the differences among sample means.

1. Simple Arithmetic Mean (x): The most popular measure for representing the entire data is the arithmetic mean, which is obtained by summing up all the observation and dividing by the total number of observations.

$\mathrm{x}=\quad \sum \mathrm{x}$

where $\mathrm{x}=$ Arithmetic mean

$\sum \mathrm{x}=$ sum of all the values of the variables $\mathrm{x}$, i.e. $\mathrm{x}_{1}, \mathrm{x}_{2} \ldots \mathrm{x}_{4}$

$\mathrm{N}=$ number of observations

2. Standard Deviation (S.D.): Standard deviation is an important measurement of dispersion and is used most commonly in statistical analysis.

S.D. $=\sqrt{ } \sum \mathrm{x}^{2}-\left(\sum \mathrm{x}\right)^{2} / \mathrm{N}$ (if size of sample is large $\left.\geq 50\right)$

Where $\sum \mathrm{x}^{2}=$ sum of squares of individual observations

$\left(\sum \mathrm{x}\right)^{2}=$ the square of the sum of individual observations

$\mathrm{N}=$ Total number of observations

3. Analysis of Variance (ANOVA): The analysis of variance frequently referred to by the contraction ANOVA, is a statistical technique specially designed to test the significance of the differences among sample means. 


\section{Results}

The study was conducted in neonatology section of Department of Paediatrics, in association with Department of Clinical Pathology, Govt. Medical College, Rajindra Hospital, Patiala. In this study, 200 healthy newborns were taken as subjects of the study. Cord blood sample was collected and TLC, DLC were measured.

Mean TLC in newborns with birth weight of $<1500$ gms was 4500/cumm, in 1500-2000 gms was 7897 $\pm 1897 / \mathrm{cumm}$, in 2001-2500 gms was $8650 \pm 1307 /$ cumm and in $>2500$ gms was $9507 \pm 1310 /$ cumm. Statistical difference in mean TLC in different groups was highly significant. $(p<0.001)$ (Table I). Mean DLC in four groups according to weight is shown in Table I, witnessing, with increase in weight of the newborn, no statistical significant difference was observed in the values of monocytes, eosinophils, basophils and immature cells. $(p>0.05)$ Whereas, the difference was stastically significant for neutrophils and lymphocytes. $(p<0.05)$

\section{TLC And DLC In Relation To Birth Weight (Gms) Of Newborns (Table I).}

\begin{tabular}{|c|c|c|c|c|c|c|c|c|}
\hline \multirow[b]{2}{*}{ Group } & \multirow{2}{*}{$\begin{array}{c}\text { No. } \\
\text { of } \\
\text { Cases }\end{array}$} & \multirow{2}{*}{$\begin{array}{c}\text { TLC } \\
\text { Mean } \pm \text { SD } \\
\text { (Reference } \\
\text { range) }\end{array}$} & \multicolumn{6}{|c|}{ Mean \pm SD (Reference range) } \\
\hline & & & $\mathrm{N}$ & $\mathrm{L}$ & M & $\mathrm{E}$ & $\mathrm{B}$ & I \\
\hline $\begin{array}{c}<1500 \\
\text { gms }\end{array}$ & 1 & $4500(4500)$ & 2600 & 1890 & $\begin{array}{c}0 \\
(0)\end{array}$ & $\begin{array}{c}0 \\
(0)\end{array}$ & $\begin{array}{c}0 \\
(0)\end{array}$ & $\begin{array}{c}0 \\
(0)\end{array}$ \\
\hline $\begin{array}{c}1500- \\
2000 \mathrm{gms}\end{array}$ & 17 & $\begin{array}{c}7897 \pm \\
1897 \\
(6000- \\
13100)\end{array}$ & $\begin{array}{c}4221 \pm 1968 \\
(1643- \\
8968)\end{array}$ & $\begin{array}{c}3563 \pm 967 \\
(1924- \\
5236)\end{array}$ & $\begin{array}{l}85 \pm 109 \\
(0-340)\end{array}$ & $\begin{array}{c}45 \pm 74 \\
(0-204)\end{array}$ & $\begin{array}{c}17 \pm 40 \\
(0-136)\end{array}$ & 0 \\
\hline $\begin{array}{c}2001- \\
2500 \mathrm{gms}\end{array}$ & 47 & $\begin{array}{c}8650 \pm \\
1307 \\
(6400- \\
13400)\end{array}$ & $\begin{array}{c}4285 \pm 994 \\
(2960- \\
7600)\end{array}$ & $\begin{array}{c}4120 \pm 1110 \\
(2000- \\
7776)\end{array}$ & $\begin{array}{c}108 \pm 129 \\
(0-510)\end{array}$ & $\begin{array}{l}69 \pm 104 \\
(0-436)\end{array}$ & $\begin{array}{c}29 \pm 74 \\
(0-370)\end{array}$ & $\begin{array}{l}3 \pm 17 \\
(0-85)\end{array}$ \\
\hline $\begin{array}{c}>2500 \\
\text { gms }\end{array}$ & 135 & $\begin{array}{c}9507 \pm 1310 \\
(4500- \\
12800)\end{array}$ & $\begin{array}{c}5086 \pm 1418 \\
(1032- \\
9600)\end{array}$ & $\begin{array}{c}4260 \pm 1002 \\
(1600- \\
7568)\end{array}$ & $\begin{array}{l}90 \pm 163 \\
(0-960)\end{array}$ & $\begin{array}{c}55 \pm 97 \\
(0-510)\end{array}$ & $\begin{array}{c}19 \pm 48 \\
(0-264)\end{array}$ & $\begin{array}{c}2 \pm 14 \\
(0-100)\end{array}$ \\
\hline \multicolumn{2}{|c|}{ Statistical Analysis } & $\begin{array}{l}\mathrm{F}=13.807 \\
\mathrm{P}=<0.001\end{array}$ & $\begin{array}{l}\mathrm{F}=5.895 \\
\mathrm{P}=0.001\end{array}$ & $\begin{array}{l}\mathrm{F}=4.001 \\
\mathrm{P}=0.009\end{array}$ & $\begin{array}{l}\mathrm{F}=0.304 \\
\mathrm{P}=0.823\end{array}$ & $\begin{array}{l}\mathrm{F}=0.437 \\
\mathrm{P}=0.727\end{array}$ & $\begin{array}{l}\mathrm{F}=0.426 \\
\mathrm{P}=0.734\end{array}$ & $\begin{array}{l}\mathrm{F}=0.279 \\
\mathrm{P}=0.841\end{array}$ \\
\hline
\end{tabular}

TLC And DLC In Relation To Length (Cm) Of Newborns (Table II).

\begin{tabular}{|c|c|c|c|c|c|c|c|c|}
\hline \multirow[b]{2}{*}{ Group } & \multirow[b]{2}{*}{$\begin{array}{l}\text { No. of } \\
\text { Cases }\end{array}$} & \multirow{2}{*}{$\begin{array}{c}\text { TLC Mean } \pm \\
\text { SD } \\
\text { (Reference } \\
\text { range) }\end{array}$} & \multicolumn{6}{|c|}{ Mean \pm SD (Reference range) } \\
\hline & & & $\mathrm{N}$ & $\mathrm{L}$ & M & $\mathrm{E}$ & $\mathrm{B}$ & I \\
\hline$<45 \mathrm{~cm}$ & 22 & $\begin{array}{c}8223 \pm 2227 \\
(4500-13400)\end{array}$ & $\begin{array}{c}4316 \pm 1843 \\
(4500- \\
13400)\end{array}$ & $\begin{array}{l}3640 \pm 1209 \\
(1890-7504)\end{array}$ & $\begin{array}{c}101 \pm 157 \\
(0-612)\end{array}$ & $\begin{array}{l}64 \pm 129 \\
(0-510)\end{array}$ & $\begin{array}{c}15 \pm 40 \\
(0-136)\end{array}$ & 0 \\
\hline $45-50 \mathrm{~cm}$ & 146 & $\begin{array}{l}9192 \pm 1263 \\
(6000-12800)\end{array}$ & $\begin{array}{c}4805 \pm 1350 \\
(1032-9600)\end{array}$ & $\begin{array}{c}4207 \pm 1010 \\
(1600-7776)\end{array}$ & $\begin{array}{c}101 \pm 162 \\
(0-960)\end{array}$ & $\begin{array}{c}62 \pm 98 \\
(0-436)\end{array}$ & $\begin{array}{l}25 \pm 60 \\
(0-370)\end{array}$ & $\begin{array}{c}3 \pm 16 \\
(0- \\
100)\end{array}$ \\
\hline$>50 \mathrm{~cm}$ & 32 & $\begin{array}{c}9555 \pm 1631 \\
(4500-12200)\end{array}$ & $\begin{array}{c}5187 \pm 1454 \\
(2520-9150) \\
\end{array}$ & $\begin{array}{c}4280 \pm 1040 \\
(1800-6400)\end{array}$ & $\begin{array}{l}52 \pm 77 \\
(0-236) \\
\end{array}$ & $\begin{array}{r}29 \pm 55 \\
(0-244) \\
\end{array}$ & $\begin{array}{l}5 \pm 22 \\
(0-94) \\
\end{array}$ & 0 \\
\hline \multicolumn{2}{|c|}{$\begin{array}{c}\text { Statistical Analysis } \\
\text { ANOVA }\end{array}$} & $\begin{array}{c}F=5.746 \\
P=0.04\end{array}$ & $\begin{array}{l}F=2.433 \\
P=0.090\end{array}$ & $\begin{array}{l}F=3.121 \\
P=0.046\end{array}$ & $\begin{array}{l}F=1.417 \\
P=0.245\end{array}$ & $\begin{array}{c}F= \\
1.566 \\
P= \\
0.212\end{array}$ & $\begin{array}{c}\mathrm{F} \\
=1.944 \\
\mathrm{P}= \\
0.146\end{array}$ & $\begin{array}{c}F= \\
0.938 \\
P= \\
0.393\end{array}$ \\
\hline
\end{tabular}


TLC And DLC In Relation To Head Circumference (cm) Of Newborns (Table III).

\begin{tabular}{|c|c|c|c|c|c|c|c|c|}
\hline \multirow{2}{*}{ Group } & \multirow{2}{*}{$\begin{array}{c}\text { No. } \\
\text { of } \\
\text { Cases }\end{array}$} & \multirow{2}{*}{$\begin{array}{c}\mathrm{TLC} \text { Mean } \pm \mathrm{SD} \\
\text { (Reference range) }\end{array}$} & \multicolumn{6}{|c|}{ Mean $\pm \mathrm{SD}($ Reference range $)$} \\
\hline & & & $\mathrm{N}$ & $\mathrm{L}$ & M & E & B & I \\
\hline$>30 \mathrm{~cm}$ & 9 & $\begin{array}{c}8273 \pm 2669 \\
(4500-13100)\end{array}$ & $\begin{array}{c}4731 \pm 2420 \\
(2600- \\
8968)\end{array}$ & $\begin{array}{c}3369 \pm 860 \\
(1890- \\
4644)\end{array}$ & $\begin{array}{c}103 \pm 135 \\
(0-340)\end{array}$ & $\begin{array}{l}37 \pm 75 \\
(0-204)\end{array}$ & $\begin{array}{l}23 \pm 48 \\
(0-136)\end{array}$ & 0 \\
\hline $\begin{array}{c}30-35 \\
\mathrm{~cm}\end{array}$ & 188 & $\begin{array}{c}9191 \pm 1416 \\
(4500-13400)\end{array}$ & $\begin{array}{c}4815 \pm 1376 \\
(1032- \\
9600)\end{array}$ & $\begin{array}{c}4198 \pm 1045 \\
(1600- \\
7776)\end{array}$ & $\begin{array}{l}94 \pm 153 \\
(0-960)\end{array}$ & $\begin{array}{c}59 \pm 98 \\
(0-510)\end{array}$ & $\begin{array}{l}21 \pm 55 \\
(0-370)\end{array}$ & $\begin{array}{c}2 \pm 14 \\
(0-100)\end{array}$ \\
\hline$>35 \mathrm{~cm}$ & 3 & $\begin{array}{c}8783 \pm 1200 \\
(7600-10000)\end{array}$ & $\begin{array}{c}4880 \pm 2258 \\
(3040- \\
7400)\end{array}$ & $\begin{array}{c}3903 \pm 1128 \\
(2600- \\
4560)\end{array}$ & 0 & 0 & 0 & 0 \\
\hline \multicolumn{2}{|c|}{$\begin{array}{c}\text { Statistical } \\
\text { Analysis } \\
\text { ANOVA }\end{array}$} & $\begin{array}{l}F=1.729 \\
P=0.180\end{array}$ & $\begin{array}{l}F=0.018 \\
P=0.982\end{array}$ & $\begin{array}{l}F=2.820 \\
P=0.062\end{array}$ & $\begin{array}{l}F=0.592 \\
P=0.554\end{array}$ & $\begin{array}{l}F=0.755 \\
P=0.471\end{array}$ & $\begin{array}{l}F=0.235 \\
P=0.791\end{array}$ & $\begin{array}{l}\mathrm{F}=0.161 \\
\mathrm{P}=0.852\end{array}$ \\
\hline
\end{tabular}

Table II shows mean values of TLC and DLC in relation to length of newborn and it was observed that mean TLC in newborns with length $<45 \mathrm{cms}$ was $8223 \pm 2227 /$ cumm, in $45-50 \mathrm{cms}$ was $9192 \pm 1263 /$ cumm and in $>50 \mathrm{cms}$ was $9555 \pm 1631$ /cumm and this difference was statistically significant. $(p<0.05)$. Whereas, when mean DLC in all the three groups was compared with respect to length, only lymphocytes showed statistically significant difference. $(p<0.05)$.

Similarly, mean TLC and DLC values were measured and compared with head circumference of newborns who were categorized into three groups as shown in table III and no statistical significant difference was observed for values of total and differential leucocyte count among the three groups. $(p>0.05)$

\section{Discussion}

Cord blood is the true indicator of hematological values at birth as it is not affected by hemodynamics changes that take place within few hours of birth. It has been studied in great detail from the beginning. In the present study Cord blood sample was collected and Total and Differential leucocyte count were measured at birth. Various authors had studied value of Total and Differential leucocyte count in new borns $[3,15,16,17,18,19]$.

Nevertheless, in most of the studies related to total and differential leucocyte count in cord blood the aim was to determine the normal reference range of these in newborns, but some studies also evaluated the effects of perinatal and neonatal events on these parameters. Many studied the effect of maternal factors viz. type of delivery and parity on total and differential leucocyte count in neonates $[6,10,20,21]$ and witnessed some significant results, but only few studies were done to evaluate the effect of neonatal factors i.e. weight of the newborn with these values [12,22]. So it was needed that a study should be done to evaluate the effect of other neonatal anthropometric factors viz. head circumference and length in addition to weight on the total and differential leucocyte count.
In our study, we studied correlation of birth weight of neonate with total and differential leucocyte count. It was found that total leucocyte count showed increasing values with rising weight of the newborn, on the other hand in differential leucocyte count only neutrophils \& lymphocytes increased significantly with weight whereas eosinophils, basophils and monocytes had no significant variation in relation to change in weight of the neonate. On the contrary, in a similar study by Samantaray $\mathrm{R}$ et al [22] where all hematological parameters except Differential leucocyte count were studied in cord blood showed higher value of TLC in SFD (small for date) babies compared to those who were born at term and AGA (appropriate for age). Whereas, an another study, done by Ali MA et al [12] related to hematological parameters in neonates showed no significant relation between total leucocyte count and weight of the neonate. Difference in findings of the two studies from our study might have been because of criteria adopted for division of the study groups. Nevertheless, none of these studies mentioned about effect of weight on differential leucocyte count.

In addition to all of the above, none of the studies done so for evaluated the relation of two other important 
neonatal anthropometric factors with total and differential leucocyte count in neonates. Thus, in our study we took one step ahead by evaluating the effect of other anthropometric factors viz head circumference and length of the neonate on cord blood total and differential leucocyte count; that have not been studied so for. Therefore, what we observed in our study was that first of all increase in total leucocyte count of the neonate was directly proportional to the length i.e. as the length of the neonate increases there is higher normal reference value of total leucocyte count.

However, length did not affect the differential leucocyte count except lymphocyte count that witnessed increase in value directly proportional to length similar to that with TLC. Secondly, the other anthropometric parameter i.e. head circumference was studied, it was found that there was no significant effect of head circumference on both total and differential leucocyte count in cord blood of a healthy newborn.

Thus, our study showed that while establishing normal reference values for TLC and DLC in neonates, it should be kept in mind that neonatal anthropometric factors viz. weight and length of the neonate affect these values to some extent in healthy newborns, whereas head circumference does not have any effect on the total and differential leucocyte count.

\section{Conclusion}

It can be inferred that total leucocyte count increases with increasing weight and length of the newborn. Similarly, in DLC neutrophils and lymphocytes increases with increasing weight, whereas, with increasing length of the newborn, only lymphocytes showed increase in value. However, head circumference has no effect on Total and differential leucocyte count in healthy newborns.

\section{Funding: Nil, Conflict of interest: Nil \\ Permission from IRB: Yes}

\section{Refrences}

1. Elder G, Hutchison R, Edinburgh MJ. 1895;41:105.

2. Aitkin J. Blood Counts in the Newborn.J. Obst. Gynae. Brit. Emp. 1902;1:414.

3. Lippman HS. A morphologic and quantitative Study of the blood corpuscles in the newborn period. Am J Dis Child. 1924;27:473.
4. Thurbleck SM, Mcintosh N. Preterm blood counts vary with sampling site. Archives of Diseases in Childhood. 1987;62:74-87.

5. Aneja S, Manchanda R, Patwari A, Sagreiya K, Bhargawa SK. Normal hematological values in newborns. Indian Pediatr. 1979;16(9):781-6.

6. Siddiqui MAR, Saxena H, Srivastava JR. A study of hematological values in newborns. Indian Pediatr. 1972;9(2):90-4.

7. Proytcheva MA. Issues in neonatal cellular analysis. Am. J.clin. Pathology. 2009;131:560-73.

8. Borna H, Borna S, Rafati SH, Haji FEBT. Umblical cord hematological variables in different modes of delivery. Tehran University Medical Journal. 2006; 64(8):49-56.

9. Sharma G, Nesin M, Feuerstein M, Bussel JB. Maternal and Neonatal Characteristics Associated with Neonatal Neutropenia in Hypertensive Pregnancies. Amer J Perinatol. 2009;26(9):683-9.

10. Chirico G, Gasparoni A, Ciardelli L, Martinotti L, Rondini G. Leukocyte Counts in Relation to the Method of Delivery during the First Five Days of Life. Biol Neonate. 1999;75:294-9.

11. Maconi M, Roflo A, Cardropoli S, Brini M, Danise P. Hematological values in healthy and small for gestational age newborns. Lab Hematol. 2005;11: $152-6$.

12. Ali MA, Shahidullah M, Hossain MA, Ahmed NU, Kawsar CA. Comparison of haematological values among different groups of low birth weight babies and normal birth weight babies. Mymensingh Med J. 2008 Jul;17(2):152-6.

13. Battaglia FC, Lubchenco LO. A practical classification of newborn infants by weight and gestational age. J Pediatr. 1967;1159-63.

14. Sood R. Examination of Peripheral Blood Film. Medical Laboratory Technology, Fourth edition. 1994:188-94.

15. Lucas WP, Deaning BF, Hoobler HR, Cox A, Jones NR, Smith FS. Blood Studies in the newborn 
(morphological, chemical, Coagulation, urobilin, and bilirubin). Am J Dis Child.1921;22:525.

16. Coulombel L,Dehan M,Tchernia G,Vial M.The number of polymorphonuclear leucocytes in relation to gestational age in the newborn.Acta Pediatr Scand.1979;68:709-11.

17. Washburn AH. Blood cells in healthy young infants. Am J Dis Child. 1935;50:413.

18. Weinberg AG, Rosenfield CR, Manroe BL, Browne R. Neonatal blood cell count in health and disease II Values for lymphocytes, monocytes and neutrophils. J Pediatr.1985;106:462-6.

19. Manroe BL, Weinberg AG, Rosenfeld CR, Browne R. The neonatal blood count in health and disease.
Reference values for neutrophilic cells. J Pediatr. 1979;95:89-98.

20. Stancheva VP, Sherman GG, Avent M, Cory BJ, Dned RN, Ballot DE. Hematological reference ranges in black very low birth weight infants. Peditr Hematol Oncol. 2002;19:91-4.

21. Noguera NI, Detarsio G, Perez SM, Bragos IM, Lanza O, Rodriguez JH. Hematological study of newborn umbilical cord blood. Medicinia. 1999;59: 446-8.

22. Samantaray R, Pradhan BB. Effect of faetomaternal factors on haematological parameters of cord blood. IOSR-JDMS. 2015;14(5):292-6.

\section{How to cite this article?}

Kumar A, Singh J, kumar I. To study the relation of anthropometric factors with total and differential leucocyte count in healthy newborns. Int J PediatrRes.2016;3(7):523-528.doi:10.17511/ijpr.2016.107.11. 